\title{
Strategic planning in financial institutions
}

\author{
Kenneth C. Krogh \\ Jenkins-Krogh International, Inc., Texas, USA
}

\begin{abstract}
The article outlines an approach to strategic planning for financial institutions in which functional strategic plans are first developed for each business unit or unique area of service in the organization. The bank's overall strategic plan is then developed by approving or modifying individual plans so that resources are channelled into areas offering the greatest potential for achievement of the bank's goals. The strategic planning cycle for each line of business should include eight planning elements: mission statement; internal analysis including the unit's strengths and weaknesses; external analysis which includes opportunities and threats in the en. vironment; goals and objectives; strategies for action; management review action; planning for implementation; and continuous evaluation of performance of both people and products in terms of the strategic plan and stated objectives. Several models are shown to illustrate the process.

S. Afr. J. Bus. Mgmt. 1982, 13: 53-60
\end{abstract}

Die artikel gee 'n oorsig van 'n benadering tot strategiese beplanning vir finansiële instellings waarvolgens funksionele strategiese planne eers vir elke bedryfseenheid of unieke area van diens in die onderneming ontwikkel word. Die bank se algehele strategiese plan word dan ontwikkel deur dié in. dividuele planne goed te keur of te wysig sodat hulpbronne gekanaliseer word na areas wat die beste potensiaal bied vir bereiking van die bank se doelwitte. Die strategiese beplanningsiklus vir elke bedryfsafdeling behoort agt beplanningselemente te behels: verklaring van missie; interne ontleding wat die eenheid se sterktes en swakhede insluit; ontleding van die eksterne omgewing wat geleenthede en bedreigings insluit; doelstellings en doelwitte; strategieë vir aksie; hersiening van planne deur topbestuur; beplanning vir implementering; en voortdurende evaluasie van die prestasie van sowel personeel as produkte volgens die strategiese plan en verklaarde doelwitte. Verskeie modelle word getoon om die proses te illustreer.

S.-Afr. Tydskr. Bedryfsl. 1982, 13: 53-60

\section{Introduction}

Most organizations devote a considerable amount of time and effort each year to the process of establishing goals and objectives and developing profit and operational plans for the ensuing year. This type of planning is generally characterized as operational or tactical planning since it is concerned largely with building on and improving the status quo.

Another dimension of planning is that which is termed as strategic planning. Strategic planning is the process of planning for change in the organization. It typically involves an on-going programme of an objective assessment of the organization's current position; its strengths and weaknesses: the opportunities and threats presented by external forces such as the actions of competitors, political and regulatory changes, social and technological changes, etc.; and finally, the development of plans or strategies and the commitment of resources to implement these strategies in order to bring about significant and positive changes in the organization. The objective is to capitalize on strengths and opportunities, to overcome weaknesses, and to anticipate the effect of changes brought about by external forces rather than being overwhelmed by these forces. One of the major benefits derived from strategic planning is the ability that it affords managers to make better decisions in their day-to-day operations by virtue of having thought out what it is they are attempting to accomplish over the longer term.

For example, banking organizations can be viewed as an aggregation of a diversified number of separate and distinct businesses offering many different products and services to different customer groups. The approach to strategic planning is to first develop functional strategic plans for each organizational unit or unique area of service. The total bank's overall strategic plan is then developed through the process of approving or modifying these individual strategic plans in order to channel the organization's resources into those areas which offer the greatest potential for achievement of the bank's goals, for example profit, quality service, and growth.

It is recommended that each functional area of the organization prepare a strategic plan centered around its products and services. The resulting strategic plans should be viewed as the long-range plans for the organization's major areas of business (service) and not merely the plan for an individual division or group. In
President, Jenkins-Krogh International, Inc., 9550 Forest Lane,

Suite 314, Dallas, Texas 75243, USA 
most instances, each of the various lines of business involves the interaction and cooperation of a number of different functional areas or groups. The final plan for a given line of business should reflect input from all of the areas involved in providing that service. As a follow-on process, individual divisions and departments may then develop their own strategic plan to support the overall line of business or service. In some instances, support areas, such as data processing and personnel, will not be able to complete their strategic plans until after the plans for the major lines of business or service have been completed and approved.

In our definition of strategic planning we said it was an on-going programme and should be thought of as a cycle: a cycle that occurs in an organization on an annual basis. The results of the first-year strategic planning cycle should produce both a 1-year plan and a 3- to 5-year plan. In subsequent years the strategic planning cycle should produce the long-range plan ( 3 to 5 years) with a 1-year update. The initial cycle will be the most time consuming and the most difficult to accomplish because of the learning and management discipline involved.

\section{Strategic planning cycle}

The strategic planning cycle for a particular line of business or functional activity should consist of the following eight planning elements:

- Mission statement

- Internal analysis

- External analysis

- Goals and objectives
- Strategies for action

- Management review action

- Implementation

- Evaluation

As stated in the introduction, the development of the strategic plan for a particular line of business or service should be coordinated with and have the benefit of the input from all departments/groups involved in providing the service involved. Proposed goals, objectives and strategies should then be reviewed in detail by a planning group or a strategic planning committee. Departments may be asked to modify their goals as a result of capital constraints on the organization, the need to give priority of resources to other areas of the organization, or for numerous other reasons. Once the various functional strategic plans have been approved, appropriate individuals will assume responsibility and accountability for the attainment of the goals and objectives established. Figure 1 presents a flow diagram of the strategic planning cycle.

\section{Mission statement}

This is a carefully thought-out, concise statement of the central purpose of the organization as it currently exists. The mission statement should clarify the nature of the organization's business describing its scope and longrange intent. It should provide the focal point around which all the organizational effort revolves. Like the total organization's mission statement, each division of department of the total organization should also have a mission statement briefly describing that organizational unit's purpose, scope and intent.

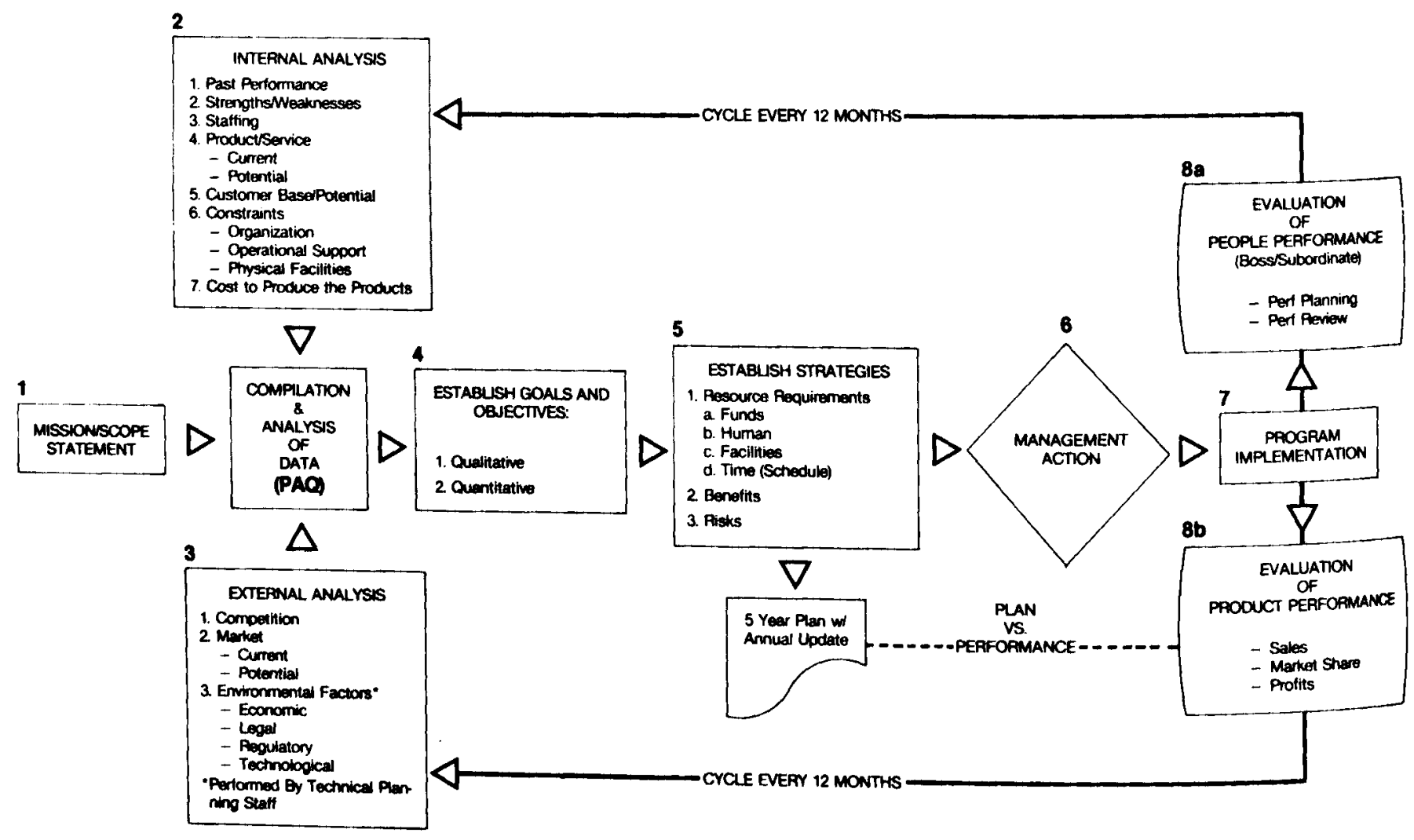




\section{Internal analysis}

A logical point of departure in any attempt to plan where a firm goes in the future is to review its progress over the past three to five years and take an objective look at how well it has performed. The firm needs to analyse its strengths, weaknesses, products/services, customer base, staff, anticipated constraints and the costs involved in past activities. To help organize this internal analysis it is recommended a committee be established and assigned the responsibilities of researching the following aspects:

\section{Past performance}

Depict the trends of the business over the past five years in terms of turnover, volumes of activity, profitability, growth or other significant measures. Comment on any significant factors that have impacted the year-to-year trends.

\section{Strengths/Weaknesses}

List in an objective manner the strong points and the weak points of the organizational unit. What is the image of the unit internally, and in the eyes of its customers?

\section{Staffing}

Present an analysis of current staff in terms of age of key personnel, experience and expertise in their field, and the degree of stability or turnover experienced in the staff.

\section{Product/Services}

Describe briefly each of the major products or services the organizational unit offers. Discuss the year-to-year growth in each of these products or services and the relative profitability of each.

\section{Customer base/Potential}

Present an analysis of the present customer base considering such matters as the number of customers served, the degree of concentration and diversity of the customer base, geographic dispersion of customers, and customer loyalty. If a significant portion of the unit's profitability is dependent on a few key customers, make an evaluation of the position with regard to each of these customers, that is relationship with key individuals, factors which could cause the firm to lose that customer, etc.

\section{Constraints}

Identify the factors in the organization that would keep its staff from doing a more effective job. This could be organization policies, or the quality of performance by other organizational units upon which the unit depends. Also consider the way the unit is organized in terms of factors such as work assignments, the adequacy of physical facilities, and resource availability.

\section{Cost to produce the products/services}

Determine the cost to produce your products or services. How much cost per unit? How profitable is it? Assistance from finance or accounting areas to determine overhead burden rates, etc., may be needed.

\section{Performance ability versus product market potential}

A final responsibility of the internal analysis committee is to evaluate each of the organization's products and ser- vices. This is a totally committee-subjective evaluation. To aid in determining whether a product/service should be harvested or divested, maintained, or invested in for continued growth, a grid has been prepared for plotting the committee's decision. This grid is shown in Figure 2.

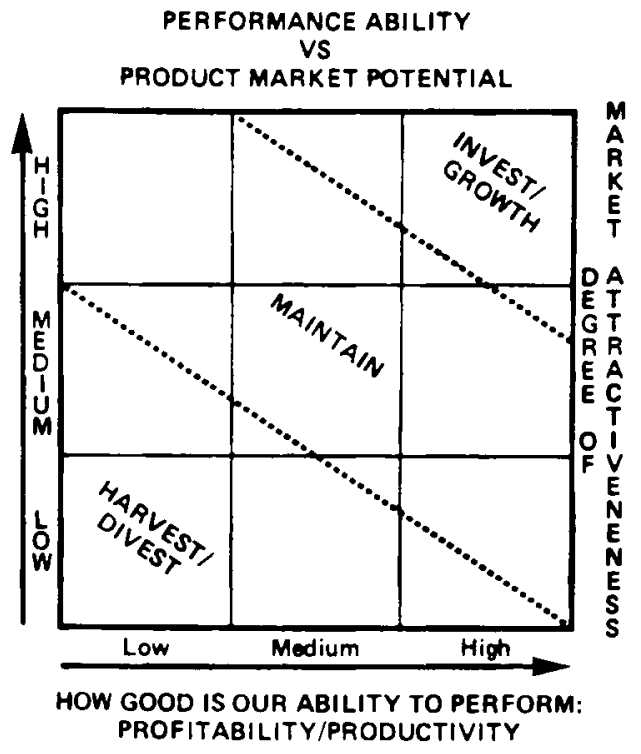

Figure 2 Performance ability vs product market potential

\section{External analysis}

In addition to looking in the organization and assessing past performance, it is also essential to look outside at various external factors that influence productivity and ability to achieve goals. To supplement the committee's efforts it may be necessary to concentrate external factfinding and analysis by assigning this aspect to a technical planning staff or engaging an outside consultant or research firm. Principal areas of research should include:

\section{Competition}

List banks, building societies, and other firms that the committee considers to be the major competition in the firm's market area. Analyse to the degree possible their strengths and weaknesses and best-guess the share of the market they currently hold.

\section{Market}

Describe in terms of geographic area and total monetary volume the current and potential market for the relevant unit's services. Estimate the share of this potential market that the unit currently serves. Indicate portions of this potential market that appear promising for further cultivation.

\section{Industry environment}

Any attempt to develop plans for the future of any business must take into consideration external forces and the environment in which the industry will be required to operate. While our crystal balls tend to be pretty cloudy, a close examination of past trends and current developments can provide considerable insight into what the firm may be faced with in the future. 
The major external forces which will impact banks and all financial institutions in the future can be grouped under the general headings of:

- Political/Regulatory

- Social

- Technological

- Economical

The major probable developments in each of these areas need to be researched and applied each time the organization completes the strategic planning cycle. The exhibit below presents an overview of the banking environment in the United States in the early 1980s. Although there are naturally many differences between the countries, it may be interesting for South African managers, and in particular bankers, to consider trends in the USA, and compare them with the situation facing their firms. They should then do a similar analysis for their particular organization unit.

\section{Overvlow of United States banking environment, early $1980 \mathrm{~s}$} Political/Regulatory

For the most part, the regulations under which banks and other financial institutions have operated for many years have had as their principal objective the maintenance of the solvency of these institutions and thereby the protection of the customers. While not necessarily intending to be so, many of these regulations have tended to be anti-competitive. This would include such matters as:

- Restricted entry of new firms into the field through stringent chartering requirements.

- Restricted geographical area served through branching limitations.

- Regulation on the amount of interest that an institution can pay on time deposits.

- Prohibition against the payment of interest on demand deposits.

- The limitation essentially of checking account services to commercial banks.

- The prohibition of banks engaging in the securities business.

In some instances in the past, regulatory agencies have gone to great lengths to prevent the failure of financial institutions. Two factors, at least, seem to be at work to change much of the above:

- Technological changes, such as electronic funds transfer services, are breaking down the geographic barriers that have insulated individual financial institutions.

- There appears to be a strong inclination in both Congress and the regulatory agencies to foster more competition among and between financial institutions, even at the expense of possibly more failures.

Specifically, over the next five years we may well see:

- A gradual expansion of branching - country-wide, state-wide, into adjoining states, nation-wide.

- Less obstruction in the chartering of new state and national banks.

- A blurring of the distinction between the various types of financial institutions - commercial banks, savings and loans, and credit unions - including the offering of third-party payment services or checking accounts by all three.

- Removal of interest rate ceilings on time deposits originally designed to promote low cost funds for home buying.

- Payment of interest on demand deposit accounts. This in turn would tend to promote the 'unbundling' of bank services, that is more services performed for fees rather than balances.

- The payment of interest on required reserve accounts at Federal Reserve Banks to eliminate the present penalty involved in Federal membership and to reduce the profit impact on banks of paying interest on demand deposits.

- An expansion of permissible services by bank holding companies including, perhaps, expansion into other regulated financial industries - insurance, securities trading and underwriting, thrift
institutions, etc.

- An ever-increasing amount of regulation, particularly at the federal level. This may well include the elimination of the ability that banks presently have of selecting their regulatory agency by shifting from a state charter to a national charter or vice versa.

The net effect of all of the above could be:

- More bank failures.

- More mergers and acquisitions, particularly of weaker banking
organizations.

- A reduction in the total number of banks in the United States.

- A reduction in the total number of independent banks.
- More intense competition between a relatively small number of very strong banking organizations operating nationally and in. ternationally.

- An increasing number of informal and formal working relationships between regional banking organizations to combat the giant international banking organizations.

Social

In recent years banks - and most other firms - have been subjected to increasing social pressures. There is every indication that this will continue and intensify in such areas as:

- Consumerism

Increased disclosure of bank rates, charges and practices.

Increased pressures to 'give the consumer a better break'.

- Increased opportunities for women, blacks and other minorities in the areas of employment, promotions, loans, etc.

- Increased pressures for recognition and special treatment for other groups such as the elderly, and the handicapped.

- Allocation and direction of bank lending into specific areas to meet social goals.

- Demands for environmental improvement. While this may have little direct effect on banks, a number of our customers are and will be strongly affected. This could affect loan demand.

\section{Technological}

After many years of discussion, progress in the whole field of electronic funds transfers is accelerating. In its simplest terms, EFT is taking banking to consumers:

- Where they work

- Where they shop

- Into their homes

All this has a number of implications for banking:

- First and foremost, the whole process is extremely expensive. Apparently only the very largest banks can afford a go-it-alone approach. For others, some form of cooperative effort is necessary.

- While EFT offers the possibility of cost displacement and cost reduction ultimately, it appears that it will be a considerable period of time before this will be a significant factor.

- There are many unresolved questions on the sharing of the cost of EFT services by business, consumers and banks.

- While historically the payment system has been almost solely the domain of commercial banks, it is apparent that not only other financial institutions, but non-financial institutions such as computer companies, communications companies and others will want to get in on the act.

- The reduction in float and the resulting reduction in deposit balances will not only shrink the earning asset base of banks, but will change many long-standing customer relationships.

Another technological change that could have a significant impact on banking is the development of inexpensive minicomputers. While large high-volume batch applications will continue to be performed in large centralized data processing centers, an increasing number of smaller applications not presently automated will be handled by relatively inexpensive minicomputers located directly in the work area. In many instances these minicomputers will be connected to the large main-frame computers and will retrieve information from or pass information to the central processing units. 


\section{Goals and objectives}

Up to this point we have reviewed past performance, assessed current operations with emphasis on strengths, weaknesses and position in the competitive marketplace, and attempted to anticipate the factors in the environment which may have an impact on the particular business in the future.

As a result, the managers doing the analysis should have a reasonably clear perspective on how effectively they are presently conducting the principal activities, how productively the resources are currently employed, what the firm's capacities are, how external factors will influence future performance, and where, in general terms, the organization is headed. This all comes down to the primary managerial challenge of the long-range planning process:

- What do we want the organization to be?

- Where should the organization be heading?

- What must the managers concerned do, and when, if they are to attain the desired results?

The first step in this process is the development of goals and objectives for the organization together with the criteria to be used in their measurement. Goals are defined as the ideal end or outcome of purposeful action. They are the important conditions and outcomes that the managers wish to attain, and toward which they direct their efforts. These can include such matters as improving profitability, increasing share of market, providing the best in services, challenging the human resource, accepting community and industry responsibilities, etc.

Objectives represent the translation of goals into measurable terms. They are primarily quantitative performance targets designed to strive for the achievement of a goal. Objectives are accompanied by specific assignments of responsibility and achievement dates. Objectives should be both realistic and challenging. Objectives are supported by statements describing measures of efficiency and effectiveness.

Measures are a means of determining whether or not objectives (and subsequently, goals) are being achieved. A measure indicates the progress made at any point in time toward reaching an objective; that is the degree to which a tangible impact on a specific situation is being realized. Measures also help to determine the rate at which resources are being expended in reaching objectives and whether or not the unit is operating within its planned budget of money, time and people. There are measures of efficiency and measures of effectiveness.

A measure of efficiency reflects an ability to perform certain tasks with skillful use of resources or to accomplish desired results with little wasted resources. Measures of efficiency indicate how economically resources are being utilized. They are usually expressed as cost per work unit produced, cost per customer, cost per employee hour, units produced per hour, or as some other expressed relationship between production and resources. Measures of efficiency do not usually provide an indication of the quality of output. Example:

- Employee compensation (salary) as a percentage of revenue.
- Percentage reduction of operating costs over the past six months.

$A$ measure of effectiveness reflects the value or quality of the product or service provided. Not in itself concerned with how efficiently resources are being utilized, an effectiveness measure provides an indication of how successfully resources are being applied to the objectives. Effectiveness measures tend to be more subjective than efficiency measures since value judgements, for example: should be quantifiable when possible, for example:

- Percentage of market gain over the past year.

- Percentage increase in ROA during 19.

\section{Strategies for action}

Strategies are defined as the specific action plans, programmes, and projects selected from among alternatives by means of which an organization intends to attain its goals and objectives. They are the commitment to specific action aimed at capitalizing on strengths, correcting weaknesses, solving problems, capitalizing on opportunities and improving performance. This is the who, what, where and how phase of the planning process in which goals are translated into unit actions and individual responsibilities, through formal planning decisions and communication sessions.

In reaching the decision point on each strategy, it is important that the range of feasible alternative courses of action available to reach a given objective be evaluated. The strategy (action plan) selected through this process of evaluation will be the one which is expected to produce optimum results in the most efficient manner, consistent with corporate goals and objectives, without affecting undesirable trade-offs or levels or risk, such as between short-term profits and long-term asset quality, for example. Not only does this evaluation of alternative strategies expose all facets of a decision to analysis, it also leads to the development of contingency plans which are useful in the event that conditions change and strategies need to be altered.

Among the factors to be considered in determining what course of action will be adopted and how it will be carried out are:

- Corporate performance goals and priorities.

- Anticipated competitor strategies/responses.

- The specific levels and types of resources required, together with their cost and availability.

- The means of deploying new resources (or redeploying existing resources).

- The cost/benefit implications.

- Acceptable trade-offs in terms of profit, risk and customer relations.

- The impact upon market or internal relationships.

- The probability of success.

- The specific dates for achievement and responsibility that management needs to assign.

In describing each strategy adopted, these supporting elements should be spelled out clearly. A brief summary should be prepared to state the case for each proposed strategy (for example, new programme or project, new product, change in pricing, different approach to existing markets, new market thrust). It should set out clearly the contribution (performance impact) the strategy will make toward attainment of the related objective(s), the 
resources required, the estimated incremental costs and incremental benefits of such programmes, projects, markets and products, and the alternatives which were considered and why they were rejected. It is necessary to describe not only what the firm plans to do and to accomplish, but how specifically it plans to do it. The following general questions are provided as guidelines:

\section{Basic profitability and performance:}

- How do you monitor product (service) profitability/ unit profitability? Criteria?

- How specifically do you plan to increase income? Fees? Service charges?

- Are there new opportunities to increase income? Where? How?

- How do you monitor the profitability of a customer relationship? At what point do you drop a relationship?

- What programmes can be initiated to better control and/or reduce staff expense and other operating costs?

- Which unit expenses are fixed and which are variable? How variable? How will you manage variable expenses more effectively?

- Are there operating efficiencies that can be realized?

- What programmes should be emphasized to capitalize on the strengths of your unit previously described? Or to minimize the impact of weaknesses? What programmes do you plan to correct these weaknesses?

\section{Marketing and competitive position:}

- What particular market segments and customer groups offer the greatest opportunity for profitable growth?

- Based upon your recognition of the services and products you provide, and the feasible limits to your ability to cover the market, what mix of services should you offer to meet the needs of these markets most profitably?

- How can the profitability of existing markets be increased (improved margins, reduced expenses, greater penetration/volume, culling, de-emphasis or abandonment of marginal or unprofitable markets or products)?

- How do you view the profit potential of new markets and/or new products/services?

- Are certain markets likely to be vulnerable to competitive rate/price cutting in the future?

- How can you enhance the quality, service to customers and pricing of your products/services (product management)?

- On what types of customers should you concentrate your calling efforts? Which are the most profitable? Least profitable? What are your priorities?

- What needs to be done to improve business development activities and calling officer skills? How can you better structure your calling programme?

- How can you cross-sell other banking services more effectively?

- What changes do you plan to improve the customer appeal of your services and products? Your delivery systems?
- How can you improve the effectiveness of your advertising and promotional programmes?

\section{Innovation}

- What new products, programmes or services do you plan to introduce? When? How? Results anticipated?

- How can your unit be more responsive to customer needs for new products or services?

- How can you encourage and implement the development and design of innovative services, programmes and products?

- What research, EDP and/or operations support do you require?

- What is your plan for implementation? Who? How? When?

- What services do you plan to delete or change? When? Impact?

\section{Productivity and efficiency:}

- What programmes do you plan in order to promote productivity increases, superior competitive performance and profitability? How will you measure/ monitor results?

- How can the organization handle increasing volumes with existing staff and facilities?

- What programmes do you plan to implement in order to improve the quality, quantity, efficiency and timeliness of your operations?

- Do you have under-utilized capacity (for example people, equipment, facilities) in any area? What do you intend to do about it?

- How efficient and effective is the organization structure and divisional working relationship communicated? Do they support your plan? What needs to be done?

- What new systems do you require in order to implement your plans?

- What research is required?

\section{Financial resources.}

- What price/cost relationships do you require to meet your profit projections?

- What is your estimate of net funds required (provided) over the planning period?

\section{Human resources:}

- What are the personnel needs required to fulfill your profit objectives? To implement your programmes? What categories and when?

- What changes, if any, do you require in recruitment, training or evaluation of performance, and how do you expect to achieve these?

- How can you develop managerial/supervisory personnel more effectively?

- What administrative, operational or structural changes are necessary to meet your profit goals?

\section{Capital expenditures:}

- What new facilities and/or equipment will you require to attain your profit objectives and over what time frame?

- How will this be accomplished, and what are the 
cost/benefits?

- What are the trade-offs?

- What space requirements do you foresee over the next three to five years? Cost? Benefits?

\section{Social responsibility:}

- How do you intend to contribute to achievement of the organization's efforts to develop and better utilize women and people of colour? What is your specific programme?

- What things can you do to promote the growth and development of the community in which you market your services?

- What programmes can be developed to respond more effectively to the consumer movement? What profit potential can be developed in doing so?

It is important that planning efforts be coordinated and integrated among all line and/or staff units which will be involved in the implementation of a plan. A review programme is intended to assess the advantages and risks of each plan, assure coordination between units of the organization in the development of related elements of their plans, evaluate the trade-offs, and provide consistency between corporate and unit goals and objectives, and between unit long-range plans throughout the organization.

\section{Contingency Planning}

It is important to consider what impact such variables as price, competition, economic conditions, technological change, and the like, could have on performance. In developing strategies and programmes, these critical variables should be identified, responsibility should be assigned for monitoring them, and an effective means (contingency plan) for dealing with each should be formulated. At minimum, consider the impact of economic/ monetary oscillations, and build sufficient flexibility into the plans to change or modify plans accordingly.

\section{Management review action}

The management review action is the process of presenting, reviewing and deciding upon the strategic plans. Each staff department or divisional manager will present to the executive management review (EMR) board (senior management) his or her strategic plan. It is recommended that the plan first be presented as a written report at least one week prior to an oral presentation to the EMR board. Each strategic plan should be presented in a standard format which includes the following elements:

1. Background information (title, staffing, etc.)

2. Mission statement

3. Products/Services

4. Internal analysis

- Past performance

- Strengths

- Weaknesses

5. External analysis

- Competition

- Market potential

- Threats

6. Recommended goals and objectives

- One year

- Three to five years

7. Strategies for action/Resources required/Follow-up plan

8. Recommendations for decision

It is the responsibility of the EMR board to review the strategic plans and decide on the degree and timing for plan implementation. It is expected that senior management will commit the resources necessary to implement the approved plans. Figure 3, entitled Strategic Planning Programme Organization, illustrates the functional role and responsibilities of the strategic planning programme.

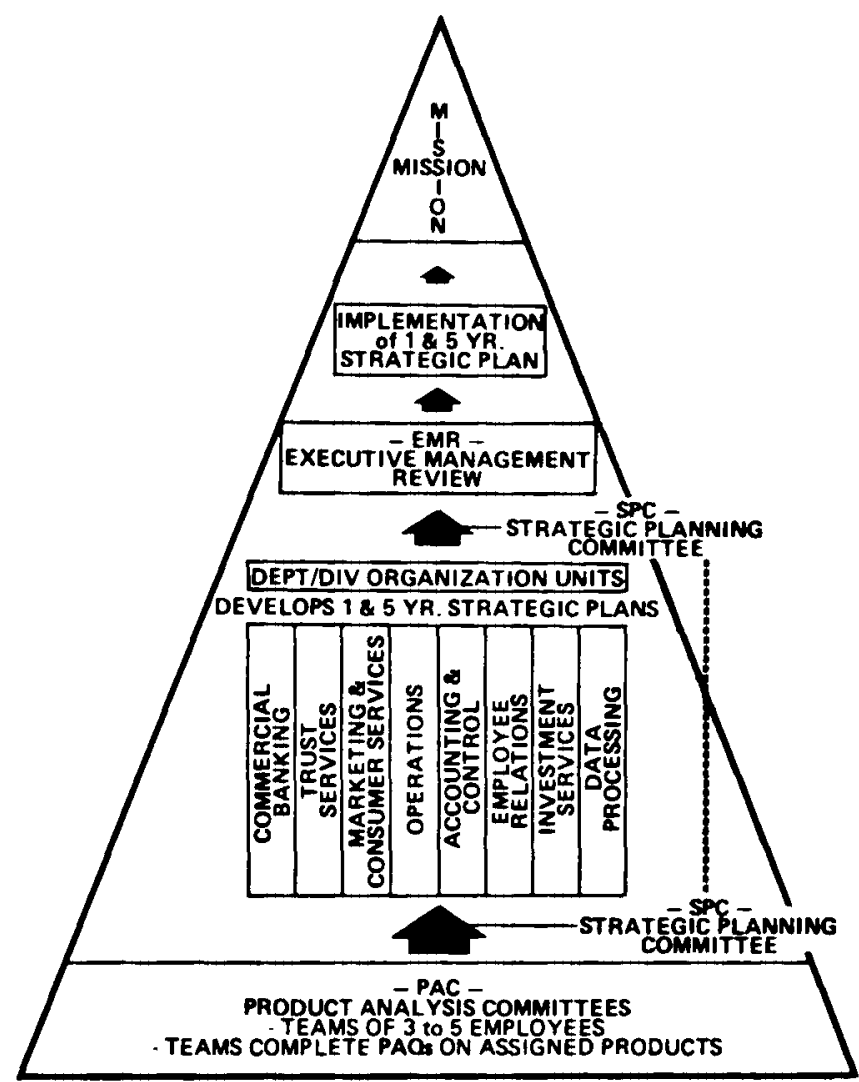

FUNCTIONPROCESS

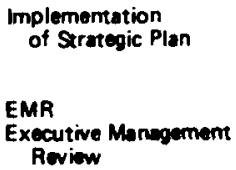

Review

SPC Strategic Planning
Committes

D/OM Depertmem/Division Manegers

PAC Product Analysis Committes:
ROLE/RESPONSIBHLITIES

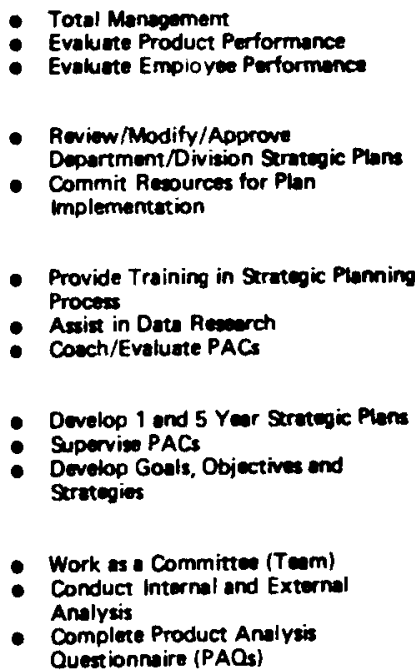

Figure 3 Strategic planning programme organization and responsibilities

\section{Implementation}

The responsibility for implementation of a management decision rests with the managers accountable for affected 
functional areas. If the plan is well thought out, the resources required to implement the plan should be identified and their expenditure approved. It is now up to the individual managers and their employees to implement their plans on a day-to-day basis in order to achieve their objectives within the resources approved. Throughout this day-to-day management/implementation process records must be kept and observations made to evaluate the effectiveness of the strategic plan.

\section{Evaluation}

The evaluation should take place on a continuous basis throughout the implementation phase of the cycle. However, it is recommended that a formal evaluation be made each year on how well the organization has performed against its plan and established objectives. The evaluation process as shown in Figure 1, on the model of the strategic planning cycle is divided into two formal assessment activities:

Evaluation of people performance. This is carried out by each boss/subordinate during their annual performance planning and performance review discussions. The personnel department assists management in this area by providing performance evaluation forms and coordinaling the activity.

Evaluation of product performance. This area is monitored by each manager against his or her department's goals and objectives. Emphasis is on sales performance, market share, and profits. Accounting and inancial planning support areas will provide record serrices and technical comparison data to aid in this evaluaion.

\section{Sonclusion}

Jpon completion of the strategic planning programme ycle, management will have a basis for:

- Establishing realistic goals and objectives.
- Making better decisions regarding Budgets

Space

People.

- Communicating with all employees through the context of the job.

- Motivating employees through responsibility and achievement.

- Rewarding employees through performance.

- Achieving the bank's goals and objectives.

The benefits from a comprehensive strategic plan can be further illustrated by a bank service model showing how the key elements of people, services, customers and success are all essential to the mission of the organization. Figure 4 presents this bank service model.

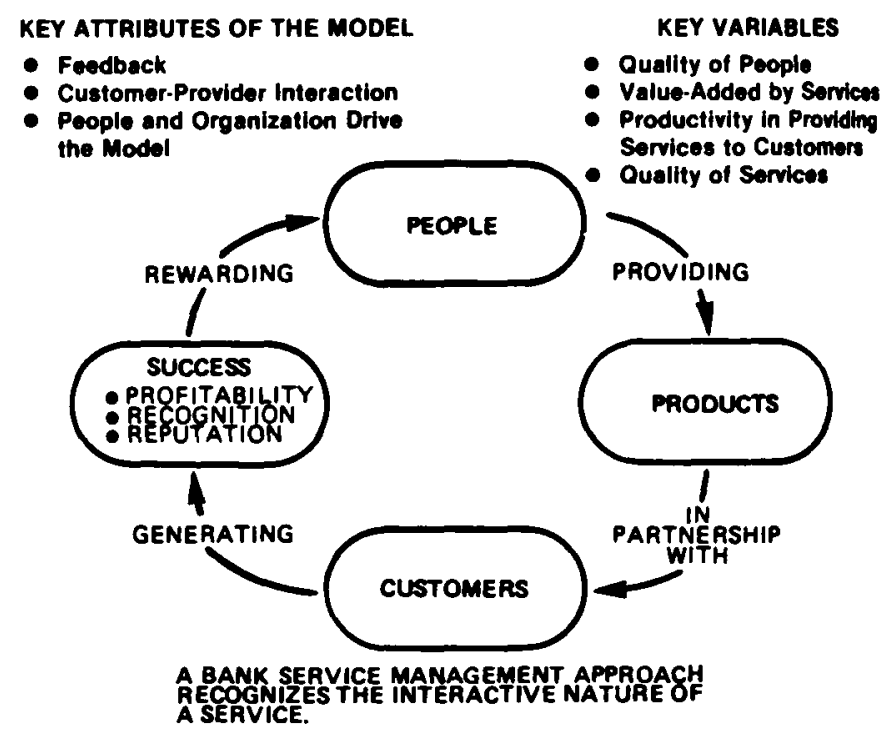

Figure 4 A bank service model

The approach outlined can enable managers to take some of the shock of change out of the future by planning for it now. 